\title{
PENILAIAN RISIKO KEGAGALAN BENDUNGAN KEDUNGOMBO SEBAGAI DASAR PRIORITAS PEMELIHARAAN BENDUNGAN
}

\author{
Rais Buldan ${ }^{1}$, Suharyanto ${ }^{2}$, dan Sriyana ${ }^{3}$ \\ ${ }^{1}$ Balai Besar Wilayah Sungai Sumatera VIII, Kementerian PUPR, Jl. Soekarno-Hatta, No.869, Palembang \\ raisbuldan@pu.go.id \\ ${ }^{2}$ Program Studi Magister Teknik Sipil, Universitas Diponegoro, Jl. Prof. Soedarto, SH, Tembalang, Semarang \\ suharyanto@lecturer.undip.ac.id \\ ${ }^{3}$ Program Studi Magister Teknik Sipil, Universitas Diponegoro, Jl. Prof. Soedarto, SH, Tembalang, Semarang \\ sriyana@lecturer.undip.ac.id
}

\begin{abstract}
A dams must always be maintained for their performance, function, and safety, so it is necessary to carry out various maintenance, repairs, and rehabilitation on dams that have been built and operating. Priority systems for the implementation of repair and rehabilitation of dams can be arranged based on the status of safety hazards or the level of risk of failure due to natural disasters or other consequences. Based on this, it is necessary to carry out an assessment of the dam to estimate the magnitude of the risk to the dam. According to the Risk Analysis Guidelines, the estimation of the probability of failure can be done using two methods, namely the traditional method and the event tree method. Based on the results of assessment analysis, the risk probability of the Kedungombo Dam with the traditional method and the event tree method is 4,010 $\times 10^{-1}$ and 1,548 $\times 10^{-3}$ where the acceptable limit conditions for the existing dam are a maximum of 1,000 $10^{-5}$. The risk probability value of the Kedungombo Dam does not meet the requirements of an acceptable risk value. Therefore, it is necessary to recommend risk reduction for the risk assessment results.
\end{abstract}

Keywords: Kedungombo Dam; Risk assessment; Traditional method; Event tree method; Risk evaluation

\begin{abstract}
ABSTRAK
Bendungan harus selalu dijaga kinerja operasi, fungsi, dan keamanannya, sehingga perlu dilakukan berbagai kegiatan pemeliharaan, perbaikan, dan rehabilitasi pada bendungan yang sudah terbangun dan beroperasi. Sistem prioritas pada pelaksanaan kegiatan perbaikan dan rehabilitasi pada bendungan dapat disusun berdasarkan status bahaya bendungan dari segi keamanan atau besarnya risiko terhadap kegagalan bendungan akibat bencana alam maupun akibat lain. Berdasarkan hal tersebut, maka perlu dilakukan penilaian risiko pada bendungan untuk memperkirakan besarnya risiko bahaya pada bendungan. Berdasarkan Pedoman Analisis Risiko, perkiraan probabilitas kegagalan dapat dilakukan dengan dua metode yaitu metode tradisional dan metode pohon kejadian (event tree). Berdasarkan hasil analisis penilaian risiko, probabilitas risiko Bendungan Kedungombo metode tradisional dan metode pohon kejadian sebesar 4,010 × $10^{-1}$ dan $1,548 \times 10^{-3}$ dimana syarat batas yang dapat diterima untuk bendungan eksisting maksimum $1,000 \times 10^{-5}$. Nilai probabilitas risiko Bendungan Kedungombo tidak memenihi syarat nilai risiko yang dapat diterima. Dengan demikian, diperlukan rekomendasi tindakan pengurangan risiko untuk risiko hasil penilaian tersebut.
\end{abstract}

Kata kunci: Bendungan Kedungombo; Penilaian risiko; Metode tradisional; Metode pohon kejadian; Evaluasi Risiko

\section{PENDAHULUAN}

Undang-Undang Republik Indonesia Nomor 24 Tahun 2007 tentang Penanggulangan Bencana pasal 40 mengamanatkan bahwa: "setiap kegiatan pembangunan yang mempunyai risiko tinggi yang menimbulkan bencana dilengkapi dengan analisis risiko bencana sebagai bagian dari usaha penanggulangan bencana". Kewajiban analisis risiko bencana secara lebih rinci disebutkan di dalam Peraturan Pemerintah Nomor 21 Tahun 2008 tentang Penyelenggaraan Penanggulangan Bencana.

Bendungan selain memberikan banyak manfaat juga memiliki risiko potensi bahaya yang dapat menimbulkan bencana apabila bendungan tersebut mengalami kegagalan atau keruntuhan. Bendungan harus selalu dijaga kinerja operasi, fungsi dan keamanannya, sehingga perlu dilakukan berbagai kegiatan pemeliharaan, perbaikan dan rehabilitasi pada 
bendungan yang sudah terbangun dan beroperasi. Sistem prioritas pada pelaksanaan kegiatan perbaikan dan rehabilitasi pada bendungan dapat disusun berdasarkan status bahaya bendungan. Selain itu anggaran untuk kegiatan rehabilitasi bendungan memiliki anggaran sangat terbatas. Berdasarkan hal tersebut, maka perlu dilakukan penilaian risiko pada bendungan untuk memperkirakan besarnya risiko bahaya pada bendungan. (Soentoro dkk., 2013).

Anggaran untuk kegiatan pemeliharaan bendungan sangat terbatas. Dengan demikian, diperlukan urutan prioritas untuk alokasi anggaran pemeliharaan bendungan berdasarkan risiko kegagalannya (Fluixá-Sanmartín dkk., 2020).

Penerapan pada bendungan besar menunjukkan bahwa metode yang diusulkan memberikan estimasi dan perbandingan risiko yang cepat, yang dapat membantu pejabat manajemen setempat melakukan evaluasi keamanan bendungan yang lebih rinci untuk informasi manajemen risiko yang berguna (Chen dan Lin, 2018).

Penilaian risiko pada bendungan yang sudah terbangun dan beroperasi bertujuan untuk mengetahui apakah risiko yang ada dapat ditoleransi, dan jika risiko bahaya tersebut tidak dapat ditoleransi maka diperlukan rencana tindakan untuk mengurangi risiko. Penilaian risiko pada bendungan yang sudah terbangun atau yang beroperasi juga bertujuan untuk menentukan prioritas atau peringkat pekerjaan perbaikan atau rehabilitasi yang diperlukan guna meningkatkan keamanan berdasarkan risiko yang ada pada bendungan tersebut (Pramudawati dkk., 2020).

Teknik utama penilaian dan pengelolaan risiko bendungan dirangkum termasuk identifikasi model gagalnya bendungan dan jalur gagalnya bendungan, perhitungan probabilitas dan konsekuensi gagalnya bendungan, keandalan SDM, penilaian risiko dan pengendalian waduk, kriteria risiko bendungan, dan keputusan risiko (Sheng dkk., 2018).

Berdasarkan pedoman teknis penilaian risiko bendungan yang dikeluarkan oleh Kementerian Pekerjaan Umum disebutkan bahwa penilaian risiko bendungan disarankan untuk dilakukan paling tidak setiap 10 tahun sekali bersamaan dengan pemerikasaan besar bagi bendungan dengan tinggi di atas $75 \mathrm{~m}$ dan/atau volume tampungan sekurang-kurangnya 100 juta $\mathrm{m}^{3}$ serta untuk bendungan yang termasuk kelas bendungan dengan tingkat bahaya tinggi menurut pedoman klasifikasi bahaya bendungan.

Bendungan Kedungombo dibangun pada tahun 1969 dan diresmikan pada tanggal 18 Mei 1991. sejak diresmikan hingga saat ini (lebih dari 30 tahun), diperlukan kegiatan penilaian risiko bendungan. Kegiatan tersebut diperlukan agar kelestarian fungsi bangunan tetap terjaga sesuai dengan yang direncanakan serta dalam rangka menentukan prioritas pekerjaan rehabilitasi yang diperlukan guna meningkatkan keamanan bendungan.

Penilaian risiko adalah proses untuk mencapai suatu rekomendasi keputusan tentang apakah risiko yang ada dapat ditoleransi dan apakah tindakan pengendalian risiko yang sekarang sudah memadai, dan apabila tidak, apakah tindakan pengendalian risiko alternatif dibenarkan atau akan dilaksanakan. Cakupan penilaian risiko adalah masukan dan keluaran dari tahapan analisis risiko dan evaluasi risiko (Indrawan dkk., 2013).

Analisis risiko adalah suatu metode yang sistematis untuk memperkirakan seberapa sering kejadian tertentu dapat terjadi dan besarnya konsekuensi akibat kejadian-kejadian yang tidak diinginkan, diidentifikasi dan disusun secara logika dan disajikan dalam bentuk gambar (Kementerian PU, 2011).

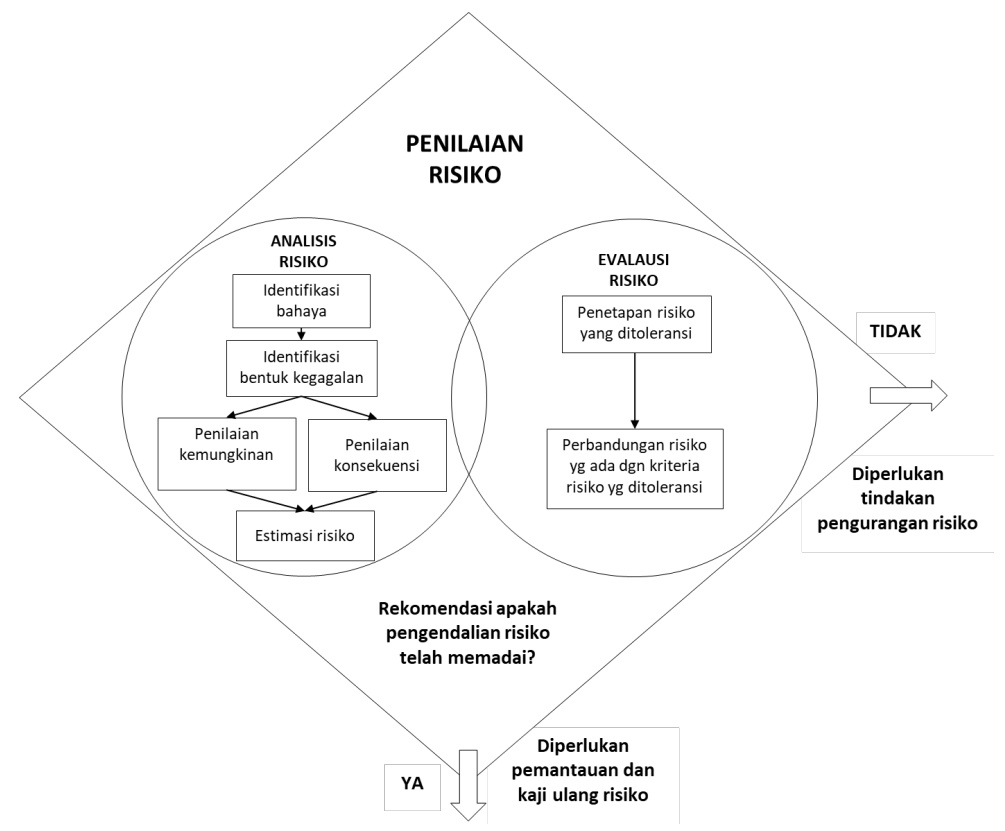

Gambar 1. Proses penilaian risiko (Sumber : Kementerian PU, 2011) 
Tahapan identifikasi bahaya adalah :

1. Pembuatan daftar semua potensi bahaya yang akan bisa terjadi dan dapat menyebabkan keruntuhan bendungan.

2. Kemudian dilakukan identifikasi bahaya-bahaya yang dapat dikeluarkan dari daftar untuk tidak dianalisis selanjutnya karena risiko yang ditimbulkan bahaya-bahaya tersebut dengan pasti dapat diabaikan.

3. Pembuatan daftar sisa potensi bahaya untuk dianalisis selanjutnya.

Analisis model kegagalan salah satunya dapat dilakukan dengan menggunakan metode FMECA (Failure Mode, Effects and Critically Analysis). Metode FMECA merupakan pengembangan dari metode FMEA (Failure Mode and Effects Analysis) dengan membuat peringkat kualitatif model-model kegagalan sesuai dengan kemungkinan dan keparahan dampak atau konsekuensinya terhadap suatu sistem.

Untuk menentukan besarnya risiko suatu bahaya/risk (R) didasarkan pada nilai kualitatif kemungkinan/probability (I) dan nilai kualitatif konsekuensi/impact (I) dari bahaya tersebut. Nilai kualitatif keyakinan/confidence (C) diperlukan untuk menentukan besarnya kekritisan/critically $(\mathrm{Cr})$ suatu bahaya. Tabel 1 hingga 5 merupakan beberapa tabel interpretasi penilaian kualitatif yang digunakan dalam Pedoman Analisis Risiko (Kementerian PU, 2011).

Tabel 1. Nilai kualitatif kemungkinan untuk analisis risiko

\begin{tabular}{|c|c|c|c|c|}
\hline \multicolumn{2}{|c|}{ Tingkat } & Deskripsi & Kriteria & Nilai \\
\hline $\begin{array}{l}\text { sangat } \\
\text { tinggi }\end{array}$ & $\mathrm{E}$ & $\begin{array}{l}\text { selalu } \\
\text { pasti }\end{array}$ & $\begin{array}{l}\text { - Dampak akan selalu terjadi } \\
\text { - Dampak akan terjadi pada tiap kejadian } \\
\text { - Kejadian sekali dalam } 1 \text { tahun }\end{array}$ & 5 \\
\hline tinggi & $\mathrm{H}$ & $\begin{array}{l}\text { mungkin } \\
\text { sekali }\end{array}$ & $\begin{array}{l}\text { - Dampak diharapkan akan terjadi } \\
\text { - Dampak akan terjadi pada hampir tiap keadaan } \\
\text { - Kejadian sekali dalam } 10 \text { tahun }\end{array}$ & 4 \\
\hline sedang & M & mungkin & $\begin{array}{l}\text { - Dampak kemungkinan akan terjadi } \\
\text { - Dampak pernah terjadi sebelumnya } \\
\text { - Dampak akan terjadi pada beberapa keadaan } \\
\text { - Kejadian sekali dalam } 100 \text { tahun }\end{array}$ & 3 \\
\hline rendah & $\mathrm{L}$ & jarang & $\begin{array}{l}\text { - Dampak dapat terjadi suatu saat } \\
\text { - Dampak pernah terjadi ditempat lain } \\
\text { - Kejadian sekali dalam } 1000 \text { tahun }\end{array}$ & 2 \\
\hline $\begin{array}{l}\text { sangat } \\
\text { rendah }\end{array}$ & $\mathrm{N}$ & $\begin{array}{l}\text { hampir } \\
\text { tidak } \\
\text { mungkin }\end{array}$ & $\begin{array}{l}\text { - Dampak dapat terjadi pada keadaan yang sangat luar biasa } \\
\text { - Kejadian serupa pernah terjadi di tempat lain } \\
\text { - Hampir tidak mungkin } \\
\text { - Kejadian dalam } 10.000 \text { tahun }\end{array}$ & 1 \\
\hline
\end{tabular}

(Sumber: Kementerian PU, 2011)

Tabel 2. Nilai kualitatif konsekuensi untuk analisis risiko

\begin{tabular}{|c|c|c|c|c|}
\hline Tingk & & Deskripsi & Kriteria & Nilai \\
\hline $\begin{array}{l}\text { sangat } \\
\text { tinggi }\end{array}$ & $\mathrm{E}$ & $\begin{array}{c}\text { Bencana } \\
\text { Dasyat } \\
\text { (Catastropic) } \\
\end{array}$ & $\begin{array}{l}\text { - Banyak penduduk terkena risiko } \\
\text { - Kerusakan pada sistem sungai utama } \\
\text { - Kerugian kerusakan diperkirakan lebih besar Rp } 30 \text { Milyar }(*)\end{array}$ & 5 \\
\hline tinggi & $\mathrm{H}$ & Besar (Major) & $\begin{array}{l}\text { - Kemungkinan sedikit penduduk terkena risiko, } \\
\text { - Kerusakan sedang pada sistem sungai utama } \\
\text { - Kerugian kerusakan diperkirakan Rp } 3 \text { Milyar sampai Rp } 30 \text { Milyar (*) }\end{array}$ & 4 \\
\hline sedang & M & $\begin{array}{c}\text { Sedang } \\
\text { (Moderate) }\end{array}$ & $\begin{array}{l}\text { - Diharapkan tidak ada penduduk terkena risiko } \\
\text { - Berdampak lokal pada air permukaan dan air tanah } \\
\text { - Kerugian kerusakan diperkirakan Rp } 300 \text { Juta sampai Rp } 3 \text { Milyar (*) }\end{array}$ & 3 \\
\hline rendah & $\mathrm{L}$ & Kecil (Minor) & $\begin{array}{l}\text { - Berdampak lokal (setempat) } \\
\text { - Kerugian kerusakan diperkirakan Rp } 3 \text { Juta sampai Rp } 3 \text { Juta }(*)\end{array}$ & 2 \\
\hline $\begin{array}{l}\text { sangat } \\
\text { rendah }\end{array}$ & $\mathrm{N}$ & $\begin{array}{l}\text { Tidak Berarti } \\
\text { (Insignificant) }\end{array}$ & $\begin{array}{l}\text { - Kemungkinan yang akan terjadi tidak tampak dengan jelas } \\
\text { - Kemungkinan tidak memerlukan perbaikan } \\
\text { - Kerugian kerusakan diperkirakan lebih kecil dari Rp } 3 \text { Juta }\end{array}$ & 1 \\
\hline
\end{tabular}

(Sumber: Kementerian PU, 2011) 
Tabel 3. Nilai kualitatif keyakinan untuk analisis risiko

\begin{tabular}{|c|c|c|c|}
\hline \multicolumn{2}{|l|}{ Tingkat } & Kriteria & Nilai \\
\hline sangat tinggi & $\mathrm{E}$ & Pasti (Certain) & 5 \\
\hline tinggi & $\mathrm{H}$ & Yakin (Confident) & 4 \\
\hline sedang & M & Meragukan (Conflicting Data) & 3 \\
\hline rendah & $\mathrm{L}$ & Tidak Jelas (Not Clear) & 2 \\
\hline sangat rendah & $\mathrm{N}$ & Sulit untuk membuat keputusan (Unable to make informed decision) & 1 \\
\hline
\end{tabular}

(Sumber: Kementerian PU, 2011)

Tabel 4. Kriteria risiko

\begin{tabular}{ccccc}
\hline \multicolumn{2}{c}{ Skor Risiko } & Kriteria Risiko & Penilaian Risiko & Tanggapan/ Response \\
\hline 17 & 25 & Risiko Sangat Tinggi & Tidak ada Toleransi & Tidak dapat diterima \\
13 & 16 & Risiko Tinggi & Tidak ada Toleransi & Tidak dapat diterima \\
9 & 12 & Risiko Sedang & Penting & Perlu perhatian dini \\
5 & 8 & Risiko Rendah & Dapat Ditoleransi & Perlu perhatian reguler \\
1 & 4 & Tidak Berarti & Tidak Berarti & Perlu dimonitor \\
\hline
\end{tabular}

(Sumber: Kementerian PU, 2011)

Tabel 5. Deskripsi verbal

\begin{tabular}{ccc}
\hline \multicolumn{2}{c}{ Deskripsi } & Probabilitas (\%) \\
\hline Pasti & Virtually Certain & 99,9 \\
Sangat Mungkin & Very Likely & 99 \\
Mungkin & Likely & 90 \\
Sedang & Neutral & 50 \\
Tidak Mungkin & Unlikely & 10 \\
Sangat Tidak Mungkin & Very Unlikely & 1 \\
Mustahil & Virtually Impossible & 0,1 \\
\hline
\end{tabular}

(Sumber: Kementerian PU, 2011)

Berdasarkan Pedoman Analisis Risiko, perkiraan probabilitas kegagalan dapat dilakukan dengan dua metode yaitu metode tradisional dan metode pohon kejadian (event tree). Metode tradisional adalah pendekatan tradisional untuk rekayasa teknik bendungan, dimana risiko dikendalikan dengan mengikuti aturan-aturan yang ditetapkan untuk perencanaan keadaan dan pembebanan, kapasitas struktur, koefisien keamanan dan langkah-langkah dalam desain. Metode tradisional menentukan probabilitas kegagalan berdasarkan hasil analisis keamanan bendungan yang telah dibandingkan dengan kriteria keamanan bendungan. Gambar 2 menunjukkan salah satu contoh hasil penentuan probabilitas kegagalan dengan menggunakan bagan pada metode tradisional (Dwi dkk., 2016).

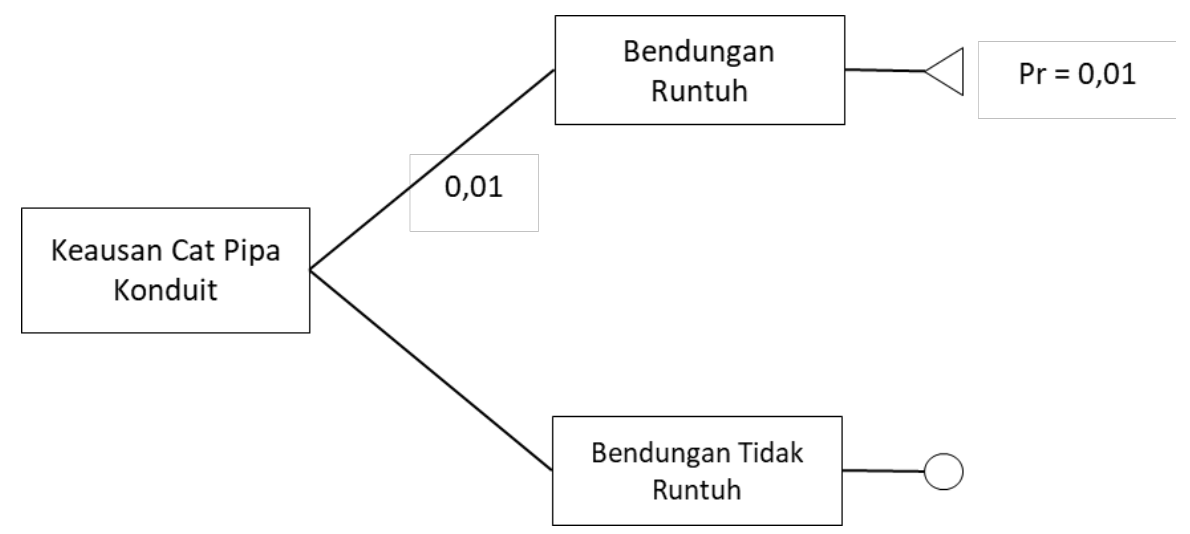

Gambar 2. Contoh penentuan probabilitas kejadian pada metode tradisional (Sumber : Dwi dkk., 2016) 
Penentuan probabilitas kegagalan pada metode pohon kejadian dilakukan dengan menyusun tahapan mekanisme kegagalan bendungan. Setiap tahapan mekanisme memiliki probabilitasnya, yang dapat ditentukan dengan menggunakan Tabel 6. Untuk mempermudah perhitungan, setiap mekanisme digambarkan dalam sebuah pohon kejadian seperti pada Gambar 3. Probabilitas pada mekanisme di ujung pohon kejadian dihitung berdasarkan probabilitas di tahap sebelumnya dan akan diklasifikasi berdasarkan kategori ekstrim (E), tinggi (H), sedang (M), rendah $(\mathrm{L})$ dan normal $(\mathrm{N})$.

Tabel 6. Skema pemetaan probabilitas

\begin{tabular}{lc}
\hline \multicolumn{1}{c}{ Deskripsi Keadaan } & Probabilitas \\
\hline Kejadian pasti terjadi & 99,9 \\
\hline Kejadian atau peristiwa teramati dalam database & 99 \\
\hline $\begin{array}{l}\text { Kejadian atau peristiwa tidak teramati, atau teramati pada suatau kejadian kecil } \\
\text { dalam database yang ada; beberapa potensi skenario kegagalan dapat diindentifikasi }\end{array}$ & 90 \\
\hline $\begin{array}{l}\text { Kejadian atau peristiwa tidak teramati dalam database yang ada. Sulit untuk } \\
\text { diidentifikasi mengenai adanya skenario kegagalan yang masuk akal, namun satu }\end{array}$ & 50 \\
skenario dapat diidentifikasi setelah dilakukan usaha yang cukup & \\
\hline $\begin{array}{l}\text { Kejadian atau peristiwa belum pernah teramati, dan tidak ada skenario yang masuk } \\
\text { akal dapat diidentifikasi, meskipun setelah dilakukan usaha yang cukup }\end{array}$ & 10 \\
\hline (Sumber : Dwi dkk., 2016) &
\end{tabular}

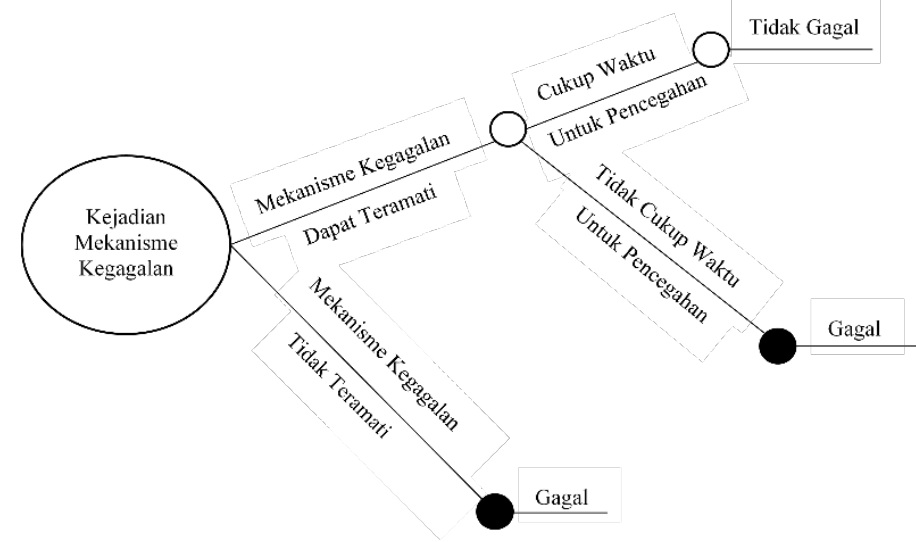

Gambar 3. Diagram mekanisme kegagalan dan tindakan pencegahan (Sumber : Dwi dkk., 2016)

Evaluasi risiko adalah suatu proses untuk menentukan prioritas risiko dengan membandingkan tingkat rasio dengan standar yang telah ditetapkan sebelumnya, dengan tingkat risiko, atau dengan kriteria yang lain (Kementerian PU, 2011). Untuk metode tradisional dan metode pohon kejadian, evaluasi dapat dilakukan dengan dilakukan plot hasil probabilitas individu dan probabilitas kelompok pada plot seperti Gambar 4.

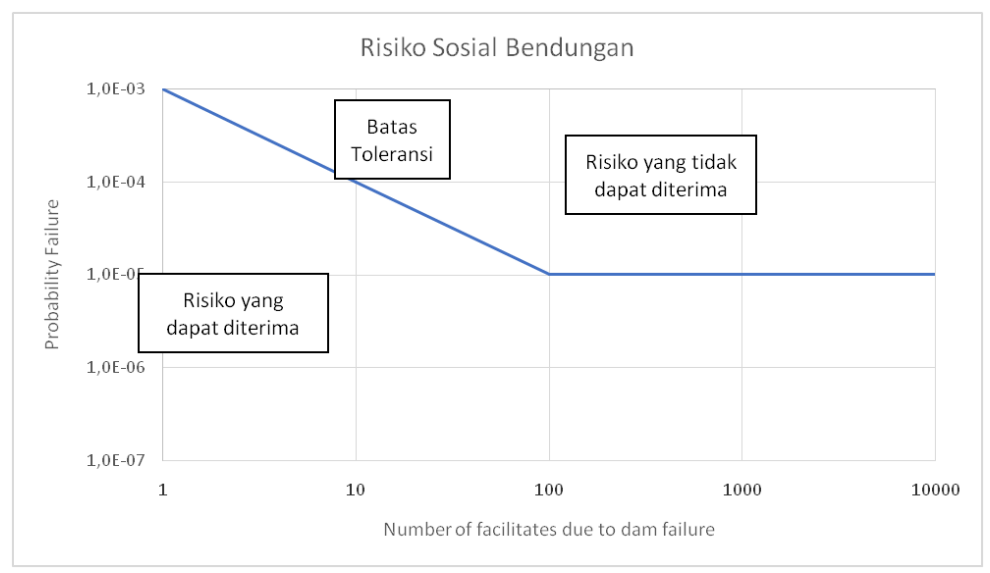

Gambar 4. Kriteria risiko yang dapat diterima untuk bendungan eksisting (Sumber : Kementerian PU, 2011) 
Penelitian ini bertujuan untuk mengetahui tingkat risiko Bendungan Kedungombo berdasarkan penilaian risiko. Penilaian risiko dilakukan berdasarkan metode tradisional dan metode pohon kejadian (event tree). Dari hasil penilaian risiko tersebut, diharapkan dapat diketahui prioritas pekerjaan perbaikan atau rehabilitasi yang diperlukan guna meningkatkan keamanan Bendungan Kedungombo.

\section{METODE PENELITIAN}

Penilaian risiko ini dilakukan pada Bendungan Kedungombo. Bendungan Kedungombo berlokasi pada pertemuan Sungai Uter dan Sungai Serang yang terletak di Dukuh Kedungombo Desa Rambat, Kecamatan Geyer, Kabupaten Grobogan, Provinsi Jawa Tengah. Secara geografi Bendungan Kedungombo berada pada koordinat $7^{\circ} 15^{\prime}$ 33" LS dan $110^{\circ} 50^{\prime} 18^{\prime}$ BT. Untuk lebih jelasnya dapat dilihat pada Gambar 5 berikut.

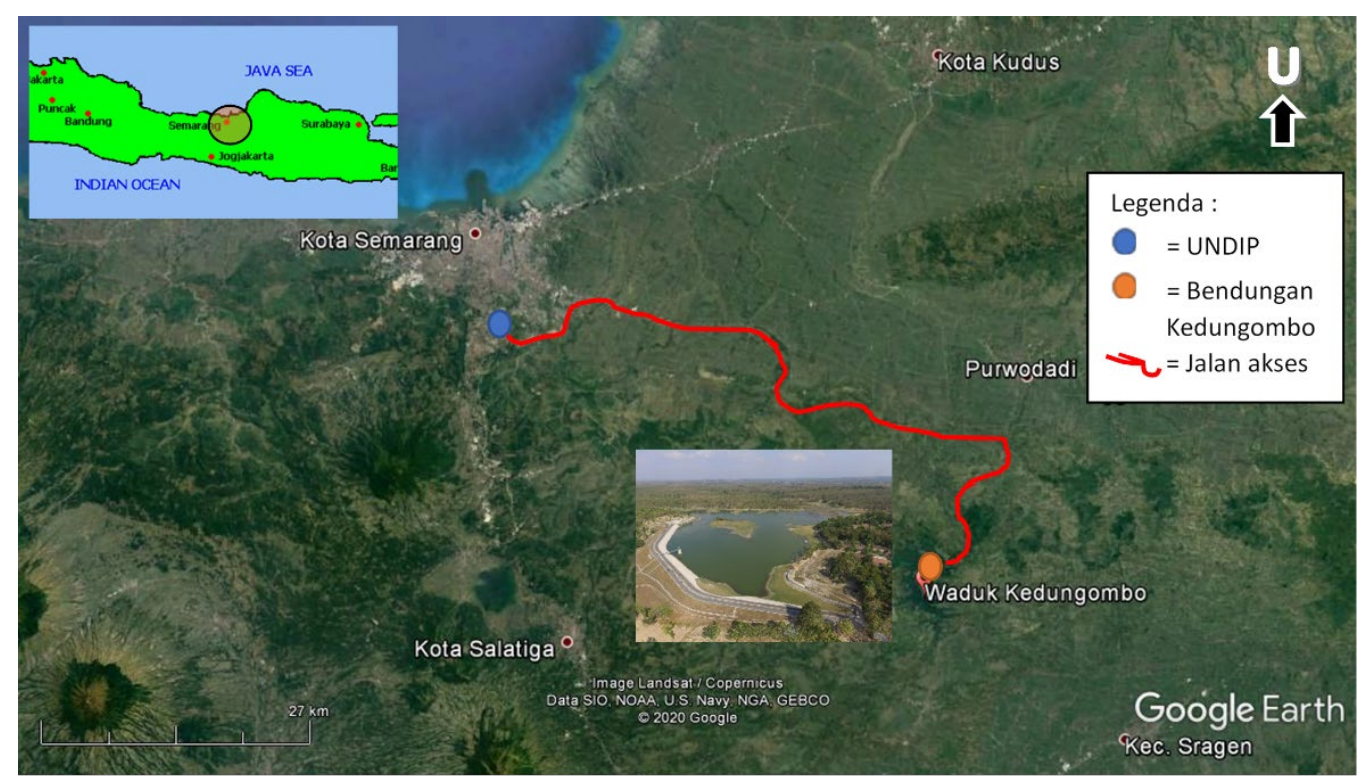

Gambar 5. Peta lokasi Bendungan Kedungombo (Sumber : Google Earth, 2021)

Data yang akan digunakan dalam penelitian ini adalah data sekunder yang diperoleh dari Balai Besar Wilayah Sungai (BBWS) Pemali Juana. Data sekunder tersebut berupa data pelaksanaan proyek pembangunan Bendungan Kedungombo. Data-data yang digunakan dalam penilaian risiko ini adalah sebagai berikut :

1. Laporan studi kelayakan

2. Laporan desain

3. Laporan geologi dan geoteknik

4. Laporan analisis dampak lingkungan

5. Laporan pelaksanaan konstruksi termasuk foto-foto pelaksanaan

6. Gambar As-builtd drawing

7. Rincian lengkap mengenai adanya modifikasi pada bendungan

8. Laporan pemantauan dan pemeriksaan keamanan bendungan

9. Laporan OP bendungan

10. Laporan kajian keamanan bendungan

\section{Laporan kejadian khusus.}

Tahapan penilaian risiko Bendungan Kedungombo secara umum digambarkan pada diagram alir Gambar 6.

Dalam mengidentifikasi potensi bahaya pada suatu bendungan yang akan dianalisis, ada tiga langkah yang perlu dilakukan yaitu, pembuatan daftar semua potensi bahaya yang akan bisa terjadi dan dapat menyebabkan keruntuhan bendungan.Dari daftar semua potensi bahaya tersebut di atas, kemudian diidentifikasi bahaya-bahaya yang dapat dikeluarkan dari daftar untuk tidak dianalisis.Pembuatan daftar sisa potensi bahaya untuk dianalisis selanjutnya. 
Dalam identifikasi bentuk/model kegagalan dimulai dengan identifikasi semua komponen bendungan yang dianalisis, kemuadian dilakukan analisis bentuk/model kegagalan untuk setiap kombinasi komponen bendungan atau bahaya bendungan. Analisis bentuk/model kegagalan bendungan dilakukan dengan menggunakan metode FMECA (Failure Mode, Effects and Critically Analysis).

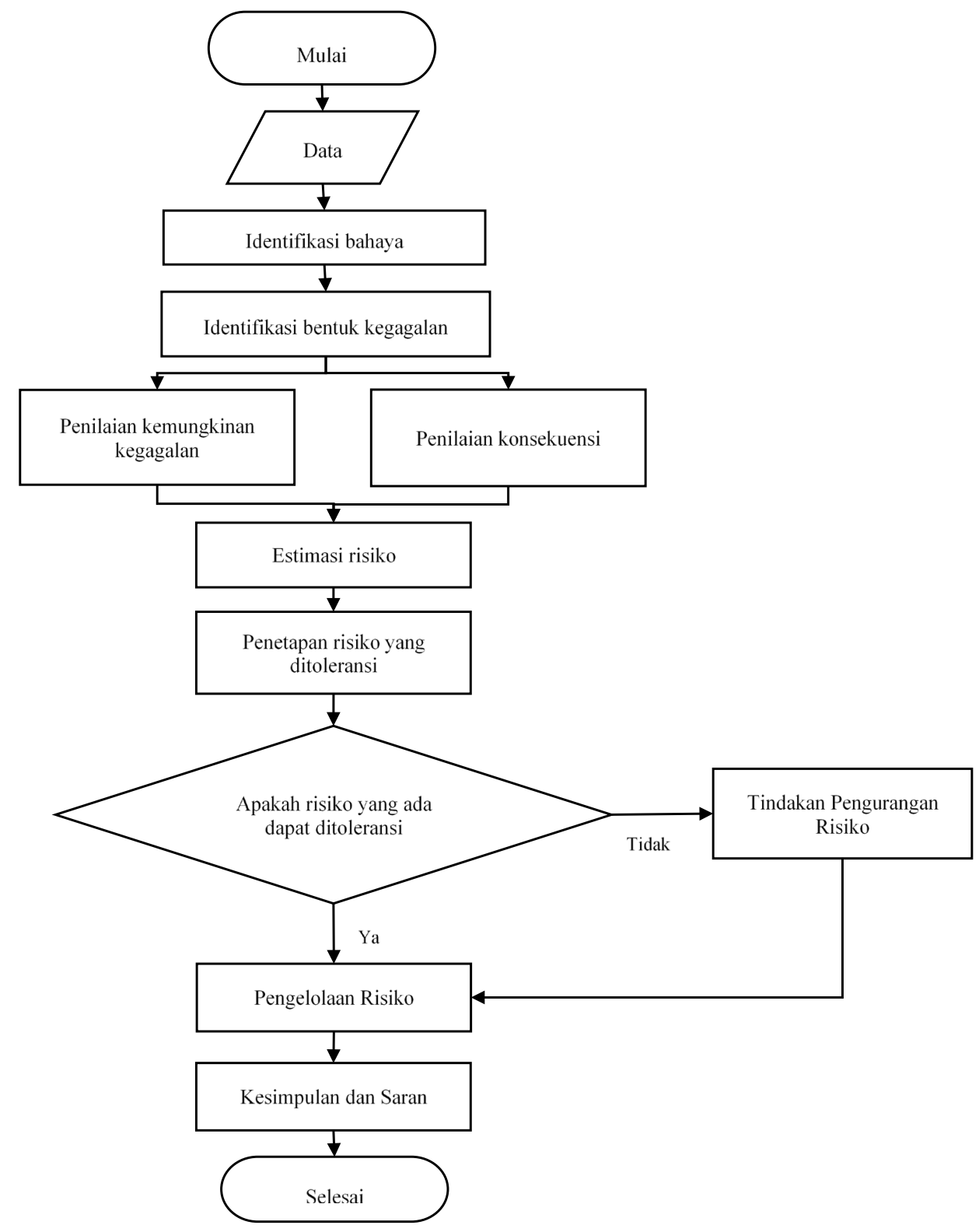

Gambar 6. Diagram alir penilaian risiko

Penentuan perkiraan probabilitas untuk elemen-elemen mekanisme kegagalan guna mendapatkan penilaian kemungkinan/probabilitas kegagalan bendungan pada keadaan operasi normal dan pada keadaan pembebanan tertentu (misalnya banjir atau gempa bumi). Penilaian kemungkinan/probablilitas kegagalan bendungan dilakukan dengan metode tradisional dan metode pohon kejadian (event tree) untuk menghitung indeks risiko.

Perkiraan besarnya dampak atau konsekuensi sebagai akibat dari kegagalan (keruntuhan) bendungan dengan mempertimbangkan karakteristik daerah genangan di hilir, keselamatan jiwa, kerugian finansial, dan lain-lain. Estimasi perkiraan besarnya probabilitas risiko kegagalan bendungan dilakukan berdasarkan penilaian perkiraan probabilitas kegagalan dan konsekuensi kegagalannya.

Penetapan risiko-risiko yang akan ditoleransi, yang mengarah ke kebijakan dan kriteria risiko yang ditoleransi dan perbandingan risiko yang ada dengan kriteria risiko yang dapat ditoleransi, yang mengarah ke rekomendasi keputusan, 
merupakan bagian dari evaluasi risiko. Evaluasi risiko dengan metode tradisional dan metode pohon kejadian dilakukan dengan mengeplotkan hasil perkiraan probabilitas kedalam grafik pada.

Hasil dari penilaian risiko adalah berupa rekomendasi mengenai apakah pengendalian risiko sudah memadai. Apabila pengendalian risiko yang ada tidak memadai, maka diperlukan langkah-langkah untuk pengurangan risiko. Apabila pengendalian risiko yang ada sudah memadai, maka diperlukan pemantauan dan kaji ulang terhadap risiko secara berkala untuk memastikan bahwa risiko yang ada tetap berada dalam batas kategori toleransi.

\section{HASIL DAN PEMBAHASAN}

\section{Identifikasi bahaya}

Identifikasi potensi bahaya Bendungan Kedungombo didasarkan pada masalah - masalah dari inspeksi visual pada kegiatan :

1. Inspeksi besar Bendungan Kedungombo yang dilaksanakan pada tanggal 6-11 Juni 2012.

2. Rencana Tindak Darurat Bendungan Kedungombo pada tahun 2017.

Kegiatan yang dilakukan adalah :

1. Mempelajari dokumen-dokumen studi terdahulu.

2. Diskusi terkait informasi teknis, kebijakan dan manajemen bendungan.

3. Observasi atau pengamatan kondisi fisik lapangan.

Hasil identifikasi bahaya Bendungan Kedungombo dapat dilihat pada Tabel 7.

Tabel 7. Skema pemetaan probabilitas

\begin{tabular}{|c|c|c|c|c|c|}
\hline No. & $\begin{array}{l}\text { Bagian/ } \\
\text { Komponen }\end{array}$ & $\begin{array}{l}\text { Kondisi } \\
\text { Beban }\end{array}$ & Potensi Bahaya & Penyebab & Mode Kegagalan \\
\hline 1 & $\begin{array}{l}\text { Tubuh } \\
\text { Bendungan }(\mathrm{Tb}) \text { : } \\
\text { Puncak }\end{array}$ & $\begin{array}{l}\text { Keadaan } \\
\text { Normal }\end{array}$ & $\begin{array}{lr}\text { Aspal } & \text { perkerasan } \\
\text { penutup } & \text { puncak } \\
\text { timbunan } & \text { mengalami } \\
\text { keretakan rambut }\end{array}$ & $\begin{array}{lr}\text { Pondasi } & \text { dan } \\
\text { campuran } & \text { aspal } \\
\text { kurang baik } & \end{array}$ & $\begin{array}{l}\text { Makin besar retakan, } \\
\text { bahaya erosi puncak } \\
\text { bertambah yang berakibat } \\
\text { penurunan tinggi jagaan }\end{array}$ \\
\hline 2 & $\begin{array}{l}\text { Tubuh } \\
\text { Bendungan (Tb): } \\
\text { Lereng hilir }\end{array}$ & $\begin{array}{l}\text { Keadaan } \\
\text { Normal }\end{array}$ & $\begin{array}{l}\text { Terdapat lubang hewan } \\
\text { (tikus) }\end{array}$ & $\begin{array}{l}\text { Habitat } \\
\text { hutan }\end{array}$ & $\begin{array}{lll}\text { Bahaya erosi } & \text { buluh } \\
\text { (piping) } & \text { pada } & \text { tubuh } \\
\text { bendungan } & & \\
\end{array}$ \\
\hline 3 & $\begin{array}{l}\text { Tubuh } \\
\text { Bendungan }(\mathrm{Tb}) \text { : } \\
\text { Lereng hilir }\end{array}$ & $\begin{array}{l}\text { Keadaan } \\
\text { Normal }\end{array}$ & $\begin{array}{l}\text { Adanya tonjolan } \\
\text { (bulge) pada daerah } \\
\text { hilir kaki bendungan }\end{array}$ & $\begin{array}{l}\text { Diduga deformasi } \\
\text { horizontal }\end{array}$ & $\begin{array}{l}\text { Deformasi } \\
\text { semakin besar, bahaya } \\
\text { longsor lereng hilir } \\
\text { bertambah }\end{array}$ \\
\hline 4 & $\begin{array}{l}\text { Instrumentasi } \\
\text { tubuh bendungan }\end{array}$ & $\begin{array}{l}\text { Keadaan } \\
\text { Normal }\end{array}$ & $\begin{array}{lr}\text { Tidak dilakukan } \\
\text { monitoring perilaku } \\
\text { tubuh bendungan }\end{array}$ & $\begin{array}{l}\text { Instrumen dan alat } \\
\text { baca rusak atau } \\
\text { tidak ada }\end{array}$ & $\begin{array}{l}\text { Perilaku yang berpotensi } \\
\text { kegagalan tidak terdeteksi }\end{array}$ \\
\hline 5 & $\begin{array}{l}\text { Bangunan } \\
\text { Pelimpah: } \\
\text { Dinding }\end{array}$ & $\begin{array}{l}\text { Keadaan } \\
\text { Normal }\end{array}$ & $\begin{array}{l}\text { Dinding pelimpah } \\
\text { sebelah kiri terdapat } 2 \\
\text { (dua) regangan dengan } \\
\text { lebar } \pm 1 \mathrm{~cm} \text { dan } \pm 4 \mathrm{~cm} .\end{array}$ & $\begin{array}{l}\text { Ada perbedaan } \\
\text { penurunan } \\
\text { (deformasi) }\end{array}$ & $\begin{array}{l}\text { Makin besar regangan, } \\
\text { bahaya keruntuhan } \\
\text { pelimpah bertambah }\end{array}$ \\
\hline 6 & $\begin{array}{l}\text { Bangunan } \\
\text { Pelimpah: } \\
\text { Kolam Olak }\end{array}$ & $\begin{array}{l}\text { Keadaan } \\
\text { Normal }\end{array}$ & $\begin{array}{l}\text { Kolam olak tertimbun } \\
\text { sedimen }\end{array}$ & $\begin{array}{l}\text { Erosi lahan sekitar } \\
\text { kolam olak }\end{array}$ & $\begin{array}{l}\text { Bahaya } \\
\text { pelimpah }\end{array}$ \\
\hline 7 & Waduk & $\begin{array}{l}\text { Keadaan } \\
\text { Normal }\end{array}$ & $\begin{array}{l}\text { Air waduk mengandung } \\
\text { zat kimiawi yang } \\
\text { mungkin dapat } \\
\text { menyebabkan korosi }\end{array}$ & $\begin{array}{l}\text { Limbah makanan } \\
\text { ikan dari keramba } \\
\text { di waduk }\end{array}$ & $\begin{array}{l}\text { Kerusakan struktur baja } \\
\text { pada } \\
\text { hidromekanikal }\end{array}$ \\
\hline
\end{tabular}




\section{Identifikasi bentuk kegagalan}

Berdasarkan hasil identifikasi bahaya yang sudah didapatkan, masing-masing komponen dianalisis lebih lanjut melalui analisis model kegagalan, kekritisan dan dampaknya (Failure Mode, Effects, and Critically Analysis/FMECA). Berdasarkan nilai kualitatif kemungkinan, konsekuensi, keyakinan, dilakukan perhitungan besarnya nilai kualitatif risiko dan kekritisan bahaya. Hasil analisis FMECA Bendungan Kedungombo dijelaskan pada Tabel 8.

Setelah dilakukan perhitungan risiko potensi bahaya, kemudian diurutkan berdasarkan tingkat besarnya risiko. Berdasarkan tingkat besarnya risiko bahaya, terdapat 4 komponen dengan skala prioritas tingkat risiko dan kritis tertinggi pada Bendungan Kedungombo, yaitu Tubuh Bendungan (Tb): Lereng Hilir akibat habitat tikus hutan; Tubuh Bendungan ( $\mathrm{Tb}$ ): Lereng Hilir akibat deformasi horizontal; Bangunan Pelimpah: Dinding; dan Bangunan Pelimpah: Kolam Olak. Urutan tingkat risiko bahaya Bendungan Kedungombo dijelaskan pada Tabel 9.

Tabel 8. Analisis FMECA Bendungan Kedungombo

\begin{tabular}{|c|c|c|c|c|c|c|}
\hline No. & Bagian/ Komponen & $\begin{array}{l}\text { Kemungkinan } \\
\text { (P) }\end{array}$ & $\begin{array}{l}\text { Konsekuensi } \\
\text { (I) }\end{array}$ & $\begin{array}{l}\text { Keyakinan } \\
\text { (C) }\end{array}$ & $\begin{array}{c}\text { Risiko } \\
(\mathrm{R})=(\mathrm{P}) \mathrm{x}(\mathrm{I})\end{array}$ & $\begin{array}{c}\text { Kekritisan } \\
(\mathrm{Cr})=(\mathrm{R}) \mathrm{x}(\mathrm{C})\end{array}$ \\
\hline 1 & $\begin{array}{l}\text { Tubuh Bendungan } \\
\text { (Tb): Puncak }\end{array}$ & 2 & 5 & 1 & 10 & 10 \\
\hline 2 & $\begin{array}{l}\text { Tubuh Bendungan } \\
\text { (Tb): lubang hewan }\end{array}$ & 3 & 5 & 2 & 15 & 30 \\
\hline 3 & $\begin{array}{l}\text { Tubuh Bendungan } \\
\text { (Tb): Deformasi }\end{array}$ & 3 & 5 & 2 & 15 & 30 \\
\hline 4 & $\begin{array}{l}\text { Instrumentasi tubuh } \\
\text { bendungan }\end{array}$ & 3 & 5 & 1 & 15 & 15 \\
\hline 5 & $\begin{array}{l}\text { Bangunan Pelimpah : } \\
\text { Dinding }\end{array}$ & 4 & 5 & 3 & 20 & 60 \\
\hline 6 & $\begin{array}{l}\text { Bangunan Pelimpah : } \\
\text { Kolam Olak }\end{array}$ & 3 & 5 & 2 & 15 & 30 \\
\hline 7 & Waduk & 1 & 3 & 1 & 3 & 3 \\
\hline
\end{tabular}

Tabel 9. Urutan tingkat risiko dan kekritisan komponen Bendungan Kedungombo

\begin{tabular}{|c|c|c|c|c|}
\hline \multirow[t]{2}{*}{ No. } & \multirow{2}{*}{ Bagian/Komponen } & \multicolumn{2}{|c|}{ Urutan } & \multirow{2}{*}{ Tindakan } \\
\hline & & Risiko & Kekritisan & \\
\hline 1 & Tubuh Bendungan $(\mathrm{Tb})$ : Puncak & 3 & 4 & Tidak Dianalisis \\
\hline 2 & Tubuh Bendungan $(\mathrm{Tb})$ : Lereng hilir (lubang hewan) & 2 & 2 & Dianalisis \\
\hline 3 & Tubuh Bendungan $(\mathrm{Tb})$ : Lereng hilir (deformasi) & 2 & 2 & Dianalisis \\
\hline 4 & Instrumentasi tubuh bendungan & 2 & 3 & Tidak Dianalisis \\
\hline 5 & Bangunan Pelimpah : Dinding & 1 & 1 & Dianalisis \\
\hline 6 & Bangunan Pelimpah : Kolam Olak & 2 & 2 & Dianalisis \\
\hline 7 & Waduk & 4 & 5 & Tidak Dianalisis \\
\hline
\end{tabular}

\section{Perkiraan probabilitas kegagalan}

1. Metode pohon kejadian

Komponen dengan urutan risiko bahaya tertinggi pada analisis FMECA diperkirakan probabilitas kejadian tahunannya dengan analisis pohon kejadian atau Event Tree Analysis (ETA). Analisis ETA menggambarkan proses mekanisme atau skenario suatu kegagalan yang mungkin dapat terjadi sebagai akibat dari suatu kejadian awal. Ringkasan probabilitas bahaya Bendungan Kedungombo dijelaskan pada Tabel 10. 
Tabel 10. Ringkasan probabilitas bahaya Bendungan Kedungombo

\begin{tabular}{|c|c|c|c|c|c|c|c|c|}
\hline No & Komponen & Penyebab & $\begin{array}{c}\text { Mode } \\
\text { Kegagalan }\end{array}$ & Ekstrim & High & Medium & Low & Normal \\
\hline 1 & $\begin{array}{l}\text { Bangunan } \\
\text { Pelimpah: Dinding }\end{array}$ & $\begin{array}{l}\text { Ada perbedaan } \\
\text { penurunan }\end{array}$ & $\begin{array}{c}\text { Dam } \\
\text { runtuh }\end{array}$ & $\begin{array}{c}1.170 \mathrm{E} \\
-04\end{array}$ & $\begin{array}{l}4.729 \mathrm{E} \\
-04\end{array}$ & $\begin{array}{c}2.409 \mathrm{E} \\
-03\end{array}$ & $\begin{array}{c}1.691 \mathrm{E} \\
-02\end{array}$ & $\begin{array}{c}9.801 \mathrm{E}- \\
01\end{array}$ \\
\hline 2 & $\begin{array}{l}\text { Tubuh Bendungan: } \\
\text { Lereng hilir }\end{array}$ & $\begin{array}{l}\text { Habitat tikus } \\
\text { hutan }\end{array}$ & $\begin{array}{l}\text { Dam } \\
\text { runtuh }\end{array}$ & $\begin{array}{c}1.381 \mathrm{E} \\
-03\end{array}$ & $\begin{array}{l}1.250 \mathrm{E} \\
-02\end{array}$ & $\begin{array}{l}0.000 \mathrm{E} \\
+00\end{array}$ & $\begin{array}{c}1.600 \mathrm{E} \\
-02\end{array}$ & $\begin{array}{l}9.701 \mathrm{E}- \\
01\end{array}$ \\
\hline 3 & $\begin{array}{l}\text { Tubuh Bendungan: } \\
\text { Lereng hilir }\end{array}$ & $\begin{array}{l}\text { Diduga } \\
\text { deformasi } \\
\text { horizontal }\end{array}$ & $\begin{array}{l}\text { Dam } \\
\text { runtuh }\end{array}$ & $\begin{array}{c}1.108 \mathrm{E} \\
-07\end{array}$ & $\begin{array}{l}1.107 \mathrm{E} \\
-04\end{array}$ & $\begin{array}{l}0.000 \mathrm{E} \\
+00\end{array}$ & $\begin{array}{c}1.889 \mathrm{E} \\
-05\end{array}$ & $\begin{array}{l}9.999 \mathrm{E}- \\
01\end{array}$ \\
\hline 4 & $\begin{array}{l}\text { Bangunan } \\
\text { Pelimpah: } \\
\text { Olak }\end{array}$ & $\begin{array}{lr}\text { Erosi } & \text { lahan } \\
\text { sekitar } & \text { kolam } \\
\text { olak } & \end{array}$ & $\begin{array}{l}\text { Dam } \\
\text { runtuh }\end{array}$ & $\begin{array}{l}5.000 \mathrm{E} \\
-05\end{array}$ & $\begin{array}{l}4.500 \mathrm{E} \\
-04\end{array}$ & $\begin{array}{c}4.500 \mathrm{E} \\
-03\end{array}$ & $\begin{array}{l}0.000 \mathrm{E} \\
+00\end{array}$ & $\begin{array}{l}9.950 \mathrm{E}- \\
01\end{array}$ \\
\hline \multicolumn{4}{|c|}{ Total } & $\begin{array}{c}1,548 \mathrm{E} \\
-03\end{array}$ & $\begin{array}{c}1,353 \mathrm{E} \\
-02\end{array}$ & $\begin{array}{c}6,909 \mathrm{E} \\
-03\end{array}$ & $\begin{array}{c}3,293 \mathrm{E} \\
-02\end{array}$ & $\begin{array}{c}3,945 \mathrm{E}+ \\
00\end{array}$ \\
\hline
\end{tabular}

\section{Metode tradisional}

Metode analisis hasil identifikasi bahaya Bendungan Kedungombo juga dilakukan dengan metode tradisional dengan menentukan mode kagagalan dan probabilitas. Hasil analisis metode tradisional Bendungan Kedungombo diplotkan pada bagan Gambar 7. Probabilitas bahaya analisis tradisional Bendungan Kedungombo dijelaskan pada Tabel 11.

\begin{tabular}{|c|c|c|c|c|c|}
\hline Komponen & Penyebab & Kondisi & \multicolumn{2}{|c|}{ Metode Tradisional } & Total \\
\hline \multirow{2}{*}{$\begin{array}{l}\text { Tubuh Bendungan } \\
\text { (Tb): Lereng hilir }\end{array}$} & \multirow{2}{*}{ Habitat tikus hutan } & \multirow{2}{*}{ Normal } & $\begin{array}{l}\text { Bendungan } \\
\text { runtuh }\end{array}$ & $1.00 \mathrm{E}-01$ & \multirow[t]{2}{*}{$1.00 \mathrm{E}-01$} \\
\hline & & & $\begin{array}{l}\text { Bendungan } \\
\text { tidak runtuh }\end{array}$ & $9.00 \mathrm{E}-01$ & \\
\hline Komponen & Penyebab & Kondisi & \multicolumn{2}{|c|}{ Metode Tradisional } & Total \\
\hline \multirow{2}{*}{$\begin{array}{c}\text { Bangunan Pelimpah } \\
\text { : Dinding }\end{array}$} & \multirow{2}{*}{$\begin{array}{l}\text { Ada perbedaan } \\
\text { penurunan } \\
\text { (deformasi) }\end{array}$} & \multirow{2}{*}{ Normal } & \multicolumn{2}{|l|}{$\begin{array}{c}\text { Bendungan } \\
\text { runtuh }\end{array}$} & $2.00 \mathrm{E}-01$ \\
\hline & & & $\begin{array}{l}\text { Bendungan } \\
\text { tidak runtuh }\end{array}$ & $8.00 \mathrm{E}-01$ & $8.00 \mathrm{E}-01$ \\
\hline Komponen & Penyebab & Kondisi & Metode $T_{r}$ & isional & Total \\
\hline \multirow{2}{*}{$\begin{array}{c}\text { Bangunan Pelimpah } \\
\text { : Kolam Olak }\end{array}$} & \multirow{2}{*}{$\begin{array}{l}\text { Erosi lahan sekitar } \\
\quad \text { kolam olak }\end{array}$} & \multirow{2}{*}{ Normal } & \multicolumn{2}{|l|}{$\begin{array}{l}\text { Bendungan } \\
\text { runtuh }\end{array}$} & \multirow{2}{*}{$\begin{array}{l}1.00 \mathrm{E}-01 \\
9.00 \mathrm{E}-01\end{array}$} \\
\hline & & & $\begin{array}{l}\text { Bendungan } \\
\text { tidak runtuh }\end{array}$ & $9.00 \mathrm{E}-01$ & \\
\hline Komponen & Penyebab & Kondisi & \multicolumn{2}{|c|}{ Metode Tradisional } & Total \\
\hline \multirow{2}{*}{$\begin{array}{l}\text { Tubuh Bendungan } \\
\text { (Tb): Lereng hilir }\end{array}$} & \multirow{2}{*}{$\begin{array}{c}\text { Diduga deformasi } \\
\text { horizontal }\end{array}$} & \multirow{2}{*}{ Normal } & $\begin{array}{c}\text { Bendungan } \\
\text { runtuh }\end{array}$ & $1.00 \mathrm{E}-03$ & \multirow{2}{*}{$\begin{array}{l}1.00 \mathrm{E}-03 \\
9.99 \mathrm{E}-01\end{array}$} \\
\hline & & & $\begin{array}{l}\text { Bendungan } \\
\text { tidak runtuh }\end{array}$ & 9.99E-01 & \\
\hline
\end{tabular}

Gambar 7. Hasil analisis metode tradisional Bendungan Kedungombo 
Tabel 11. Ringkasan probabilitas bahaya Bendungan Kedungombo

\begin{tabular}{cllc}
\hline No & \multicolumn{1}{c}{ Komponen } & \multicolumn{1}{c}{ Penyebab } & Probabilitas \\
\hline 1 & Bangunan Pelimpah : Dinding & Ada perbedaan penurunan (deformasi) & $2.00 \mathrm{E}-01$ \\
2 & Tubuh Bendungan $(\mathrm{Tb})$ : Lereng hilir & Habitat tikus hutan & $1.00 \mathrm{E}-01$ \\
3 & Tubuh Bendungan $(\mathrm{Tb})$ : Lereng hilir & Diduga deformasi horizontal & $1.00 . \mathrm{E}-03$ \\
4 & Bangunan Pelimpah : Kolam Olak & Erosi lahan sekitar kolam olak & $1.00 . \mathrm{E}-01$ \\
\hline
\end{tabular}

\section{Evaluasi risiko}

Berdasarkan hasil analisis probabilitas ekstrim individu dan probabilitas kelompok metode tradisional dan metode pohon kejadian, nilai probabilitas risiko Bendungan Kedungombo berada di atas nilai risiko yang dapat diterima. Perbandingan dan plot nilai grafik nilai probabilitas ekstrim individu dan probabilitas kelompok terhadap nilai batas metode tradisional dapat dilihat di Tabel 12 dan Gambar 8. Perbandingan dan plot nilai grafik nilai probabilitas ekstrim individu dan probabilitas kelompok terhadap nilai batas metode pohon kejadian dapat dilihat di Tabel 13 dan Gambar 9.

Tabel 12. Status probabilitas bahaya Bendungan Kedungombo metode tradisional

\begin{tabular}{lccc}
\hline \multicolumn{1}{c}{ Kriteria } & Hasil Analisis & Batas & Status \\
\hline Probabilitas ekstrim individu diambil dari per bagian & $2.000 \mathrm{E}-01$ & $1.00 \mathrm{E}-05$ & Tidak memenuhi \\
Probabilitas ekstrim kelompok diambil dari jumlah ekstrim & $4.010 \mathrm{E}-01$ & $1.00 \mathrm{E}-05$ & Tidak memenuhi \\
Kriteria risiko sosial pada grafik & - & - & Tidak Memenuhi \\
\hline
\end{tabular}

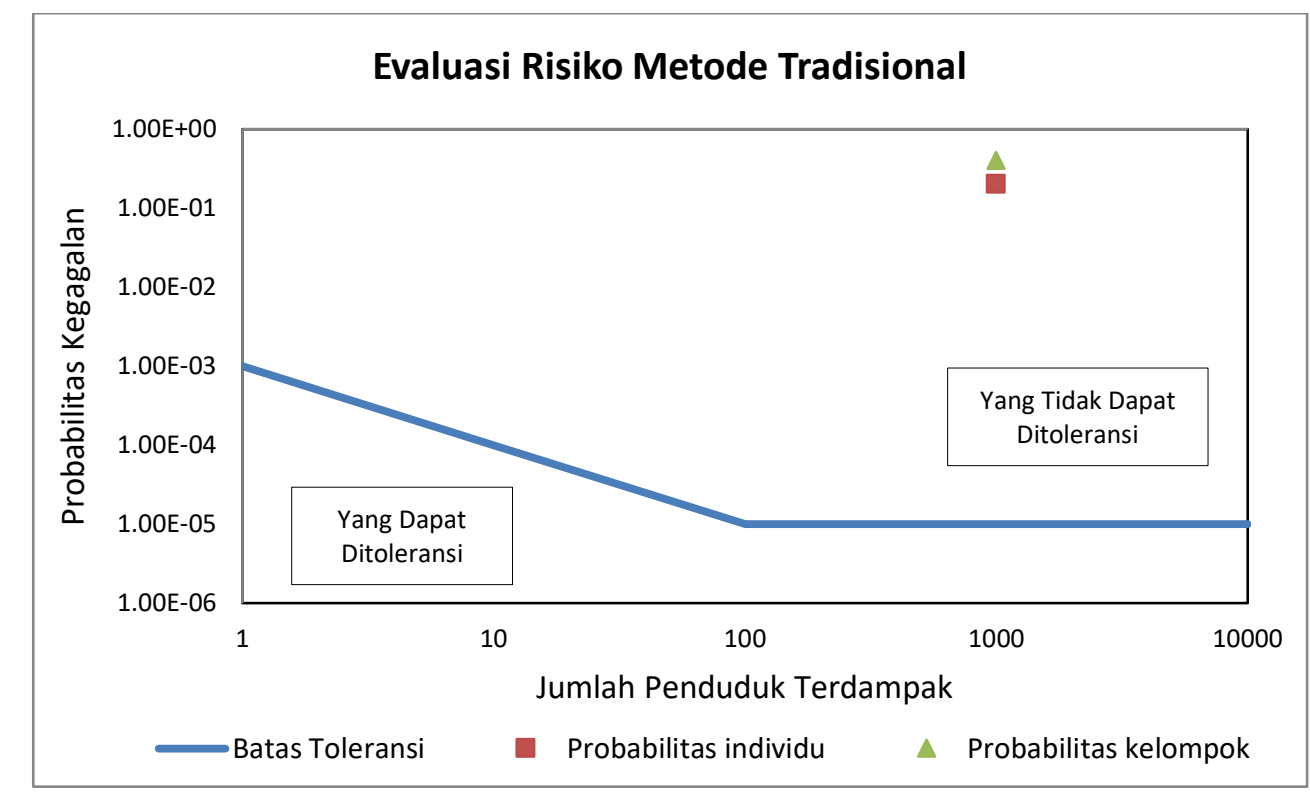

Gambar 8. Hasil analisis risiko metode tradisional

Tabel 13. Status probabilitas bahaya Bendungan Kedungombo metode pohon kejadian

\begin{tabular}{lccc}
\hline \multicolumn{1}{c}{ Kriteria } & Hasil Analisis & Batas & Status \\
\hline Probabilitas ekstrim individu diambil dari per bagian & $1.381 \mathrm{E}-03$ & $1.00 \mathrm{E}-05$ & Tidak memenuhi \\
Probabilitas ekstrim kelompok diambil dari jumlah ekstrim & $1,548 \mathrm{E}-03$ & $1.00 \mathrm{E}-05$ & Tidak memenuhi \\
Kriteria risiko sosial pada grafik & - & - & Tidak memenuhi \\
\hline
\end{tabular}




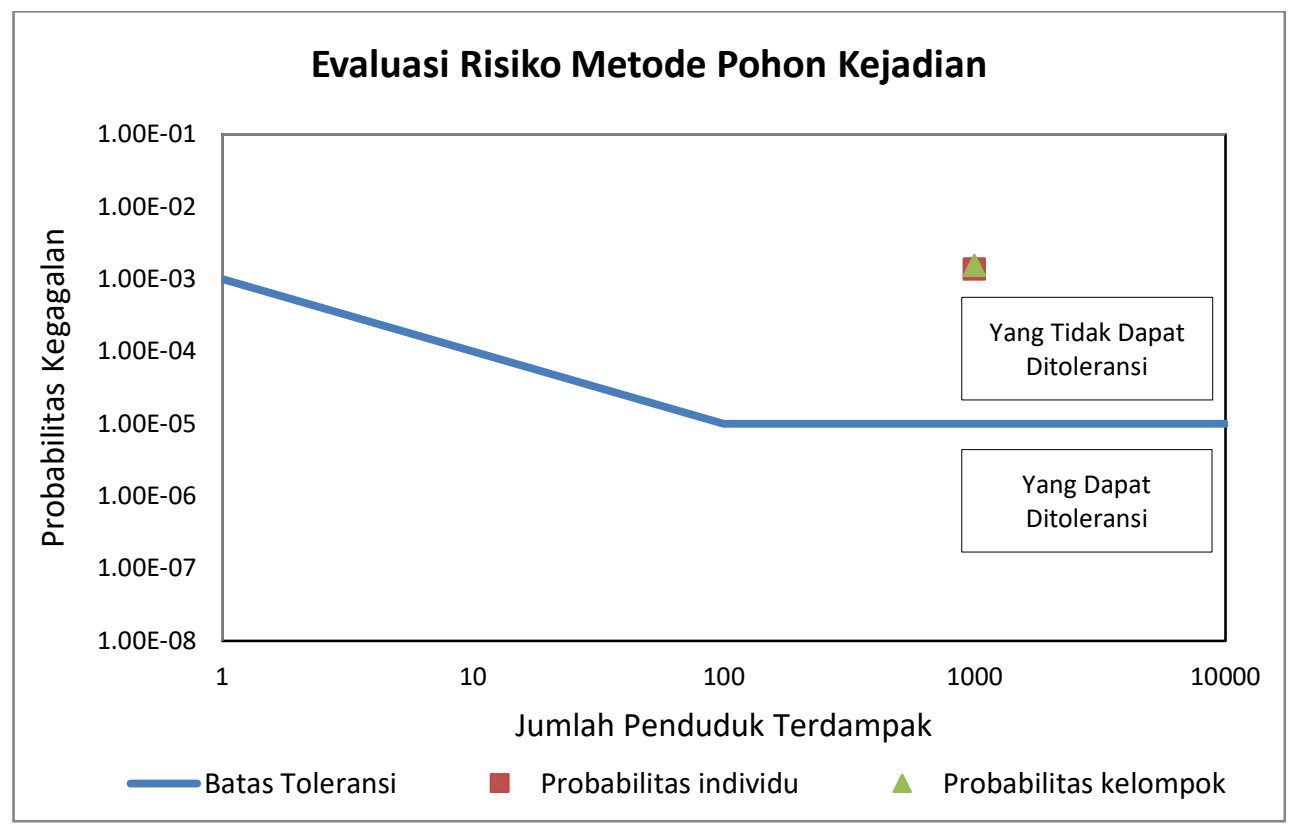

Gambar 9. Hasil analisis risiko metode pohon kejadian

\section{Rencana tindakan pengurangan risiko}

Rekomendasi tindakan pengurangan risiko untuk masalah/risiko individu yang diidentifikasi dan dianalisa, usulan TPR dan prioritas pelaksanaan dapat dilihat pada Tabel 14. Untuk masalah yang tidak diidentifikasi perlu ditangani sebagai kewajiban rutin pemeliharaan dan penyelenggaraan keamanan bendungan.

Tabel 14. Tindakan pengurangan risiko dan prioritas

\begin{tabular}{|c|c|c|c|c|c|}
\hline No. & Lokasi & Masalah/Kasus & Probabilitas & Prioritas & Usulan Tindakan \\
\hline 1 & $\begin{array}{l}\text { Tubuh } \\
\text { Bendungan: } \\
\text { Puncak }\end{array}$ & $\begin{array}{l}\text { Aspal perkerasan penutup } \\
\text { puncak timbunan mengalami } \\
\text { keretakan rambut }\end{array}$ & $\begin{array}{c}\text { Tidak } \\
\text { dianalisa }\end{array}$ & Sedang & $\begin{array}{l}\text { Perbaikan perkerasan aspal dan } \\
\text { perkerasan }\end{array}$ \\
\hline 2 & $\begin{array}{l}\text { Tubuh } \\
\text { Bendungan: } \\
\text { Lereng hilir }\end{array}$ & $\begin{array}{l}\text { Terdapat lubang hewan } \\
\text { (tikus) }\end{array}$ & $1,1170 \mathrm{E}-04$ & Tinggi & $\begin{array}{l}\text { Pemantauan hewan di lereng hilir } \\
\text { secara rutin dan penutupan lubang } \\
\text { yang sudah terbentuk }\end{array}$ \\
\hline 3 & $\begin{array}{l}\text { Tubuh } \\
\text { Bendungan: } \\
\text { Lereng hilir }\end{array}$ & $\begin{array}{l}\text { Adanya tonojolan (bulge) } \\
\text { pada daerah hilir kaki } \\
\text { bendungan }\end{array}$ & $1,381 \mathrm{E}-03$ & Tinggi & $\begin{array}{l}\text { Pembuatan titik tetap sebaga } \\
\text { acuan. pemantauan tonjolan secara } \\
\text { rutin (sebulan sekali) }\end{array}$ \\
\hline 4 & $\begin{array}{l}\text { Instrumen } \\
\text { tubuh } \\
\text { bendungan }\end{array}$ & $\begin{array}{l}\text { Tidak dilakukan monitoring } \\
\text { perilaku tubuh bendungan }\end{array}$ & $\begin{array}{c}\text { Tidak } \\
\text { dianalisa }\end{array}$ & Tinggi & $\begin{array}{l}\text { Pemeliharaan dan pergantian } \\
\text { peralatan, peningkatan kualitas } \\
\text { pembacaan data dan pelaporan }\end{array}$ \\
\hline 5 & $\begin{array}{l}\text { Bangunan } \\
\text { Pelimpah: } \\
\text { Dinding }\end{array}$ & $\begin{array}{l}\text { Dinding pelimpah sebelah } \\
\text { kiri ada } 2 \text { (regangan dengan } \\
\text { lebar } \pm 1 \text { dan } \pm 4 \mathrm{~cm} \text {. }\end{array}$ & $1.108 \mathrm{E}-07$ & $\begin{array}{l}\text { Sangat } \\
\text { Tinggi }\end{array}$ & $\begin{array}{l}\text { Penutupan regangan dengan sand } \\
\text { sheet }\end{array}$ \\
\hline 6 & $\begin{array}{l}\text { Bangunan } \\
\text { Pelimpah: } \\
\text { Kolam Olak }\end{array}$ & $\begin{array}{lll}\text { Kolam } & \text { olak } & \text { tertimbun } \\
\text { sedimen } & & \end{array}$ & $5.000 \mathrm{E}-05$ & Tinggi & $\begin{array}{l}\text { Perbaikan sungai di hilir pelimpah } \\
\text { dan penertiban pemanfaatan lahan } \\
\text { di sekitar kolam olak }\end{array}$ \\
\hline 7 & Waduk & $\begin{array}{l}\text { Air waduk mengandung zat } \\
\text { kimiawi yang mungkin dapat } \\
\text { menyebabkan korosi }\end{array}$ & $\begin{array}{c}\text { Tidak } \\
\text { dianalisa }\end{array}$ & $\begin{array}{l}\text { Sangat } \\
\text { Rendah }\end{array}$ & $\begin{array}{l}\text { Pembatasan izin keramba } \\
\text { maksimum } 1 \% \text { dari muka air pada } \\
\text { elevasi minimum }\end{array}$ \\
\hline
\end{tabular}




\section{KESIMPULAN DAN SARAN}

Kesimpulan dari hasil penilaian risiko Bendungan Kedungombo adalah penilaian risiko dengan menggunakan metode tradisional dan metode pohon kejadian menunjukkan risiko Bendungan Kedungombo tidak dapat diterima. Meskipun demikian, hasil penilaian risiko yang tidak dapat diterima tidak serta merta menunjukkan bendungan dalam kondisi bahaya. Namun diperlukan upaya-upaya perbaikan guna meminimalisir dampak terjadinya kegagalan. Beberapa saran rekomendasi tindakan untuk pengurangan risiko yaitu :

1. Perbaikan perkerasan aspal dan perkerasan di puncak bendungan.

2. Pemantauan hewan di sekitar lereng hilir secara rutin dan penutupan lubang yang sudah terbentuk.

3. Pembuatan titik tetap sebagai acuan pemantauan. pemantauan tonjolan secara rutin (sebulan sekali).

4. Pemeliharaan dan pergantian peralatan, termasuk peningkatan kualitas pembacaan data dan pelaporan.

5. Penutupan regangan dengan sand sheet.

6. Perbaikan alur sungai di hilir pelimpah dan penertiban pemanfaatan lahan di sekitar kolam olak.

7. Pembatasan izin keramba maksimum $1 \%$ dari muka air pada elevasi minimum.

\section{DAFTAR PUSTAKA}

BBWS Pemali Juana. (2012). Laporan Inspeksi Besar Bendungan Kedungombo. Kementerian PUPR. Semarang.

BBWS Pemali Juana. (2017). Laporan Rencana Tindak Darurat Bendungan Kedungombo. Kementerian PUPR. Semarang.

Chen, Y., \& Lin, P. (2018). The Total Risk Analysis Of Large Dams Under Flood Hazards. Water (Switzerland), $10(2)$.

Dwi Y., C., Juwono, P. T., \& Yuliani, E. (2016). Analisis Probabilitas Risiko Kegagalan Bendungan Gerokgak Berdasarkan Metode Pohon Kejadian (Event Tree). Jurnal Teknik Pengairan, 7, 7-16.

Fluixá-Sanmartín, J., Escuder-Bueno, I., Morales-Torres, A., dan Castillo-Rodríguez, J. T. (2020). Comprehensive Decision-Making Approach For Managing Time Dependent Dam Risks. Reliability Engineering And System Safety, 203.

Indrawan, D. (2013). Penilaian Indeks Risiko Metode Modifikasi Andersen Dan Modifikasi ICOLD Untuk 12 Bendungan Di Pulau Jawa. Jurnal Sumber Daya Air. 9(2), 93-102.

Kementerian PU. (2011). Pedoman Teknis Penilaian Risiko. Jakarta.

Pramudawati M. A. H., Mahdi I.T., Ranisa G. (2020). Penilaian Risiko Keamanan Bendungan Di Jawa Timur. Jurnal Teknik Hidraulik, 11(2), 93-102.

Pemerintah Republik Indonesia (2007). Undang-Undang Republik Indonesia Nomor 24 Tahun 2007 tentang Penanggulangan Bencana.

Pemerintah Republik Indonesia (2008). Peraturan Pemerintah Nomor 21 Tahun 2008 tentang Penyelenggaraan Penanggulangan Bencana.

Sheng, J., Li, D., Cai, Q., \& Peng, X. (2018). Research progress and its practice of key techniques for dam risk assessment and management, Journal SCIENTIA SINICA, 48(10), 1057-1067

Soentoro, E. A., Purnomo, A. B., \& Susantin, S. H. (2013). Study on Dam Risk Assessment as a Decision-Making Tool to Assist Prioritizing Maintenance of Embankment Dam. The 2nd International Conference on SIBE. 205219. 
Penilaian Risiko Kegagalan Bendungan Kedungombo

Rais Buldan, et al.

Sebagai Dasar Prioritas Pemeliharaan Bendungan 